\title{
PEMANFAATAN DAN POTENSI DUA JENIS ETLINGERA SEBAGAI TANAMAN HIAS DAN BUNGA POTONG DI BOGOR
}

\author{
Dina Handayani \\ Jurusan Biologi, Fakultas MIPA, Universitas Negeri Medan. \\ Email: dyna_h84@yahoo.co.id
}

\begin{abstract}
ABSTRAK
Etlingera masih ditanam di pekarangan rumah penduduk tanpa ada perlakuan khusus. Masyarakat Bogor hanya memanfaatkan Etlingera untuk keperluan pribadi, seperti bahan masakan, bahan wewangian, dan bahan obat-obatan tradisional. Masyarakat belum memanfaatkan Etlingera sebagai tanaman hias dan potong. Padahal Etlingera memiliki bentuk dan warna perbungaan yang menarik sehingga berpotensi untuk dikembangkan sebagai tanaman hias dan bunga potong.
\end{abstract}

Kata kunci: Pemanfaatan Etlingera, Bogor.

\section{UTILIZATION AND POTENTIAL OF TWO ETLINGERA TYPES AS DECORATIVE PLANTS AND FLOWER IN BOGOR}

Etlingera is still planted in the yard of the houses without any special treatment. The Bogor people only use Etlingera for personal use, such as cooking materials, perfumery, and traditional medicinal materials. People have not used Etlingera as an ornamental and cutting plant. Whereas Etlingera has an interesting shape and color of inflorescence so it has potential to be developed as an ornamental plant and cut flowers.

Keywords: Etlingera Utilization, Bogor.

\section{Pendahuluan}

Tanaman Etlingera cukup dikenal oleh masyarakat Bogor. Pada umumnya mereka mengenal dua jenis yaitu Etlingera elatior (Jack) R.M. Sm. (honje hedjo) dan Etlingera hemisphaerica (Blume) R.M. Sm. (honje beureum).

Masyarakat Bogor masih menanam dan memanfaatkan tanaman honje sebagai bahan masakan, bahan wewangian, dan bahan obat-obatan tradisional. Ibrahim dan Setyowati (1999) telah memaparkan pemanfaatan lain dari honje berbunga merah darah adalah sebagai tanaman hias dan bunga potong. Pendapat tersebut juga didukung oleh Wong (2008) yang mengatakan honje banyak dimanfaatkan sebagai tanaman hias dan bunga potong.

Masyarakat Bogor belum mengenal honje sebagai kultivar tanaman hias dan bunga potong sehingga kedua pemanfaatan tersebut belum ditemukan di Bogor. Padahal honje sudah dibudidayakan di negara-negara Asia Tenggara sebagai kultivar tanaman hias dan bunga potong (Ibrahim dan Setyowati 1999). Honje yang sudah dibudidayakan sebagai tanaman hias dan bunga potong adalah E. elatior dan E. hemisphaerica. Ada pun kultivar dari E. elatior antara lain Bloody Mary, Almost White, Frilly Pink, Red Torch, Burma Pink Torch, Emi-rose Torch, Evita's Rose Torch, Grace, Ice Rose, Lu-lu, Maya, Pink Spyder, Pink Torch, Porcelain Torch, Rose, dan Thai White (HSI 2013, VA 2015). Kultivar dari E. hemisphaerica antara lain Black Tulip, Cerise Tulip, Red Artiste, Tulip Torch, dan Pink Tulip (VA 2015).

\section{Bahan dan Metode}

Data pemanfaatan diperoleh dengan metode wawancara sambil lalu terhadap pedagang dan penduduk (Walujo 2004). Responden berjumlah 16 orang terdiri dari 1 orang di Pasar Caringin, 1 orang di Pasar Gunung Batu, 2 orang di Pasar Bogor, 1 orang di Pasar Ramayana, 2 orang di Kecamatan Dramaga, 1 orang di Kelurahan Baranangsiang Kecamatan Bogor Timur, 1 orang di Desa Gunung Leutik Kecamatan Ciampea, 1 orang di Desa Taman Sari dan 1 orang Desa Situ Daun di Kecamatan Tenjolaya, 2 orang di Kampung Angsana Kecamatan Leuwiliang, 1 orang di Kampung Babakan dan 1 orang Kampung Anyer Sari di Kecamatan Jasinga, 1 
orang di Kecamatan Kemang, 1 orang di Villa Botany di Desa Tajur Halang Kecamatan Cijeruk. Hasil

\section{Hasil dan Pembahasan \\ Pemanfaatan honje di Bogor}

Berdasarkan eksplorasi diketahui keberadaan tanaman honje di Bogor saat ini masih ditanam di pekarangan rumah tanpa ada pemeliharaan khusus. Sebagian besar masyarakat memanfaatkan untuk kebutuhan pribadi dan sangat sedikit untuk tujuan komersial. Kenyataan ini terlihat dari sedikitnya ketersediaan honje di beberapa pasar. Masyarakat Bogor saat ini memanfaatkan semua variasi honje untuk kegunaan yang sama, yaitu sebagai bahan masakan, bahan wewangian, bahan obat-obatan tradisional, racun menangkap kepiting.

\section{Bahan masakan}

Pada saat ini honje dimanfaatkan sebagai bahan campuran dalam masakan sayur lodeh, sayur daun singkong, sayur asem, ikan asem pedas, pepes ikan, opor ayam, opor bebek, ayam goreng, dan rujak tumbuk. Tunas daun dan kuncup yang dihaluskan bersama bumbu-bumbu lain dapat menambah aroma dan cita rasa dalam masakan sayur lodeh, opor ayam, opor bebek dan rujak tumbuk. Batang yang dimemarkan dapat menghilangkan aroma amis ayam sebelum digoreng. Rasa pedar, getir dan harum yang kuat pada tunas daun dan kuncup perbungaan membuat masyarakat memanfaatkan kedua bagian ini untuk bahan masakan. Daun dapat digunakan sebagai pembungkus masakan pepes. Buah merupakan salah satu komposisi dalam rujak untuk acara tujuh bulanan ibu hamil.

Pemanfaatan honje di masa lalu yang terlupakan oleh masyarakat Bogor yaitu kuncup dan buah sebagai pengganti buah asam (tamarinde). Bahkan masyarakat tidak mengetahui buah matang sebagai manisan (Heyne 1927; Ibrahim dan Setyowati 1999), padahal Heyne (1927) mengatakan bahwa tanaman ini dibudidayakan karena buahnya dapat diolah menjadi manisan yang enak dan didistribusikan dari Kebun Raya.

\section{Bahan wewangian}

Pada saat ini honje masih dimanfaatkan sebagai bahan wewangian. Batang semu yang dimemarkan dan dicampur dengan air dimanfaatkan untuk memandikan bayi. Heyne (1927) juga mengatakan pemanfaatan yang sama yaitu batang semu sebagai wewangian untuk memandikan mayat.

\section{Bahan obat-obatan tradisional}

Masyarakat Bogor saat ini memanfaatkan honje sebagai bahan obat-obatan tradisional. Batang wawancara disajikan dalam bentuk deskripsi.

semu dimemarkan dan dicampur air hangat dapat dimanfaatkan sebagai obat penurun panas dan menghilangkan bekas campak. Batang semu yang dimemarkan dan dicampur dengan bahan lain juga digunakan sebagai obat asma. Air dari batang diteteskan ke mata sebagai obat sakit mata, sedangkan untuk obat sakit gigi air dari batang dicampurkan air garam lalu dikumur-kumur. Batang semu dan kuncup perbungaan yang direbus atau dikukus dapat digunakan sebagai obat pencuci darah, bisul, menghaluskan kulit, menambah nafsu makan dan menurunkan berat badan. Kuncup perbungaan yang dihaluskan dimanfaatkan sebagai parem untuk ibu hamil dan dipercaya dapat mempermudah persalinan.

\section{Racun menangkap kepiting}

Batang semu dimemarkan dan diletakkan dekat sarang kepiting merupakan racun untuk menangkapnya. Pemanfaatan ini belum tercatat pada masa lalu.

\section{Pewarna alami}

Penggunaan rimpang sebagai pewarna alami kuning (Heyne 1927) merupakan pemanfaatan yang tidak diketahui oleh masyarakat Bogor saat ini.

\section{Potensi honje sebagai tanaman hias dan bunga potong}

E. elatior dan E. hemisphaerica memiliki bentuk dan warna perbungaan yang indah dan menarik bila digunakan dalam rangkaian bunga. Keindahan bentuk dan warna perbungaan tersebut berpotensi untuk dibudidayakan sebagai tanaman hias di pekarangan rumah dan bunga potong yang dapat digunakan sebagai titik sentral rangkaian. Kedua pemanfaatan tersebut lebih bernilai ekonomi daripada hanya digunakan sebagai bahan masakan, bahan wewangian, bahan obat-obatan tradisional, dan racun menangkap kepiting.

E. elatior perbungaan putih (Gambar 1) lebih berpotensi bila dikembangkan sebagai tanaman hias. Hal ini diperkirakan karena spesies ini memiliki aroma yang tidak begitu kuat sehingga masyarakat kurang memanfaatkannya sebagai bahan masakan.

Perawakan honje yang berumpun dan mencapai tinggi $6 \mathrm{~m}$ membutuhkan lokasi penanaman cukup luas. Jika pekarangan rumah penduduk kurang luas maka dapat menghalangi cahaya dan sirkulasi udara yang masuk ke dalam rumah. Kondisi seperti itu dapat menurunkan minat masyarakat untuk menanam honje. Pemanfaatan kuncup perbungaan sebagai bahan masakan dan 
bahan obat-obatan tradisional. Kedua kondisi ini diperkirakan merupakan masalah dalam pengembangan potensi honje sebagai tanaman hias dan bunga potong.

Penanaman honje dalam pot, pemangkasan batang semu bila terlalu rimbun atau tinggi dan pemberian zat pengatur tumbuh yang merangsang pembungaan dapat dilakukan untuk mengatasi masalah-masalah tersebut. Pemangkasan batang semu diperkirakan dapat merangsang pembungaan karena di dalam batang semu terdapat tunas daun. Pada tunas daun banyak ditemukan senyawa semacam gibberellin yang dapat merangsang perpanjangan batang dan menekan pembungaan (Harjadi 2009).

\section{Variasi bentuk dan warna perbungaan honje di Bogor}

Eksplorasi honje di Bogor menemukan beberapa variasi bentuk dan warna perbungaan dari dua spesies yang ditanam di pekarangan rumah. Kedua spesies tersebut antara lain E. elatior perbungaan gasing merah, merah muda, dan putih, serta E. hemisphaerica perbungaan cangkir merah dan merah muda (Gambar 1).
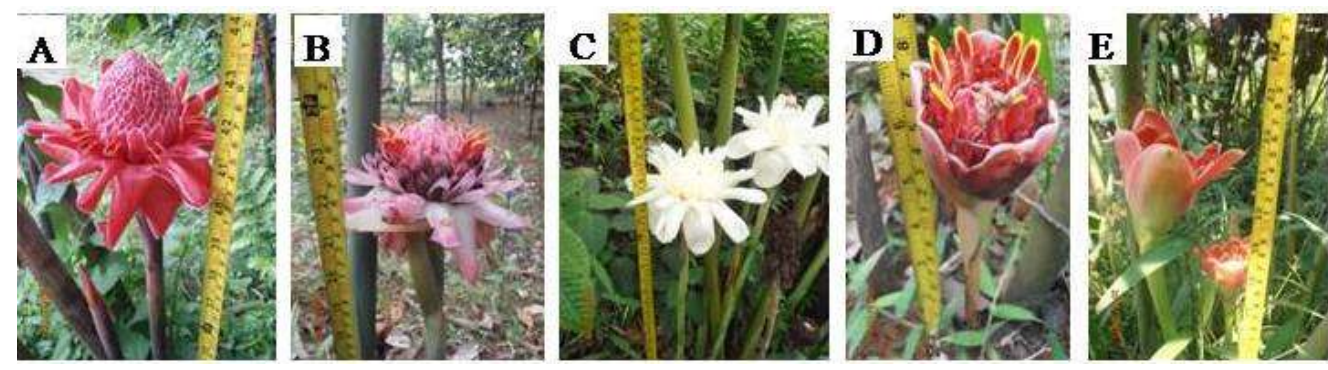

Gambar 1 Variasi perbungaan pada E. elatior (A-C) dan E. hemisphaerica (D-E) di Bogor. A. Perbungaan gasing merah, B. Perbungaan gasing merah muda, C. Perbungaan gasing putih, D. Perbungaan cangkir merah, E. Perbungaan cangkir merah muda.

\section{Kesimpulan}

Masyarakat Bogor memanfaatkan semua variasi honje untuk kegunaan yang sama, yaitu sebagai bahan masakan, bahan wewangian, bahan obat-obatan tradisional, dan racun menangkap kepiting. E. elatior dan E. hemisphaerica berpotensi untuk dibudidayakan sebagai tanaman hias dan bunga potong.

\section{Daftar Pustaka}

Harjadi S.S. 2009. Zat Pengatur Tubuh. Jakarta: Penebar Swadaya. hlm 42.

[HSI] Heliconia Society International. 2013. Etlingera Cultivar Program. [Internet]. [diunduh 01 Maret 2015]. Tersedia pada: www.heliconia.org\#!etlingera/c7oh.

Heyne K. 1927. Indonesische Nuttige Planten. Jilid ke3. Badan Litbang Departemen Kehutanan Indonesia, penerjemah. Jakarta (ID): Yayasan

Wong W. 2008. Light Up Your Garden with a Torch Ginger. Green Culture Singapore Feature Article for April 2008. hlm 1-7.
Sarana Wana Jaya. Translated to be: Tumbuhan Berguna Indonesia. hlm 628-631.

Ibrahim H., Setyowati F.M. 1999. Etlingera Giseke In: de Guzman CC, Siemonsma JS, editors. Plant Resources of South-East Asia No. 13: Spices. Leiden, The Netherlands: Backhuys Publisher. hlm 123-126.

[VA] Vivero Anones. 2015. Available Heliconias, Gingers, Musas and other related plants in the order Zingiberales (Rhizomes \& Potted Plants) February 2015. [Internet]. [diunduh 02 Maret 2015]. Tersedia pada: http://viveroanones.com/VAWEBSITE/Helico nias.htm.

Walujo E.B. 2004. Pedoman Pengumpulan Data Keanekaragaman Flora. Rugayah, Widjaja E.A, Praptiwi, editor. Bogor (ID): Puslit-LIPI. hlm 81. 